\title{
ON-LINE AND OFF-LINE ECG AND MOTION ACTIVITY MONITORING SYSTEM FOR ATHLETES
}

\author{
Stasys Korsakas ${ }^{1}$, Alfonsas Vainoras ${ }^{1}$, Liudas Gargasas ${ }^{1}$, Vytenis Miškinis ${ }^{1}$, \\ Rimtautas Ruseckas ${ }^{1}$, Vidmantas Jurkonis ${ }^{1}$, Algè Vitartaité ${ }^{1}$, Jonas Poderys ${ }^{1,2}$ \\ Kaunas University of Medicine ${ }^{1}$, Lithuanian Academy of Physical Education ${ }^{2}$, Kaunas, Lithuania
}

Stasys Korsakas. Doctor of Technical Sciences, Senior research Associate of the Laboratory for the Automation of Cardiovascular Investigations, Institute of Cardiology of Kaunas University of Medicine. Research interests — automatization of cardiology investigations.

\begin{abstract}
The aim of this paper is to present a new ECG and motion activity monitoring and on-line analysis system for athletes. The developed system is intended to facilitate the coach in optimizing and individualizing the training of elite athletes.

The hardware system consists of the device for registration of ECG and accelerometer signals and wireless transmission to computer. The coach software works in two modes: on-line version is used during training and off-line version is designed for detailed data analysis after training. The new method for respiration frequency evaluation was developed and checked on 28 persons, and in most cases the developed algorithm correctly evaluated the respiration frequency of the investigated persons. The evaluation of athlete's functional state from calculated and measured parameters and formation of warning signals (green - normal state, yellow — limitary state and red — premonitory state) is based on the analysis applying Moore and Mealy automata algorithms. The software for the evaluation of the patient's activity was tested on 11 healthy students: the increase in physical activity level during the brisk walk was 1.4 times higher compared to the level during the slow walk, and during the jogging sessions it was 1.89 times higher than during the slow walk.

The results obtained during the investigations show that the developed ECG and motion activity monitoring system with two packages of software allows to measure cardio respiratory changes and changes in intensities of physical activity under daily conditions. The comprehensive off-line analysis by monitoring data provides the possibility for coaches to make more detailed analysis of cardio respiratory changes and changes in intensities during training.
\end{abstract}

Keywords: monitoring system for athletes, electrocardiogram, accelerometry, respiration frequency.

\section{INTRODUCTION}

$\mathrm{T}$ The coach should seek to be a facilitator rather than a director during the training process; he is also responsible for the consideration of the possible outcomes (e. g. injury, overtraining, stress) that might arise due to incorrect training program (Cross, 1999). In order to improve training and coaching performance by individualization of activity there is a need for information technology that could monitor and provide feedback on physiological parameters.
Researchers were interested in increasing the performance of sportspeople by logging the results during training, on-line or off-line analysis and presentation of the analysis results to the coach and athletes, preventing injuries during rehabilitation of sportspeople (Glaros et al., 2002). However, the amount of information they provide is not enough for the coach. Usually only one physiological parameter, i. e. the heart rate (HR) is measured. The physiological parameters are 
needed for functional state evaluation of a sportsman or sportswoman for optimising his or her performance during the training process (Vainoras, 2002; Kellerman, 2006; Poderys, 2006). The aim of this study was to develop the monitoring system for monitoring cardio respiratory changes during sports training lessons and daily living activities and executing on-line and off-line data analysis. This study was the part of EUREKA project HEART GUARD (Korsakas et al., 2006). The main task of this project was to develop the personal wireless ECG and motion activity device and warning system for long term monitoring of home care patients or sportspeople.

\section{METHODS}

System architecture. The system architecture design includes the definition of system components and implementation requirements, specification of requirements for each unit, specification of interactions inside the system including data transfer standards. The architecture of ECG and motion activity monitoring system is presented in Figure 1. It consists of wireless ECG and ac-

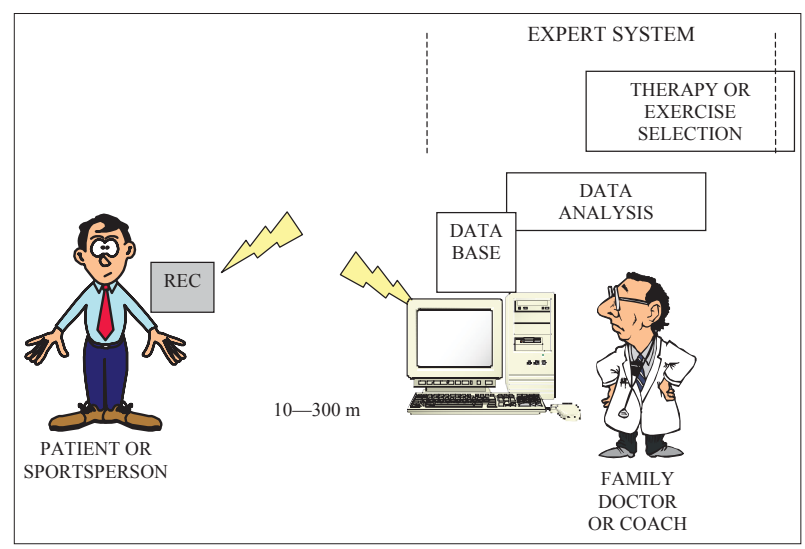

Figure 1. The architecture of ECG and motion activity monitoring system

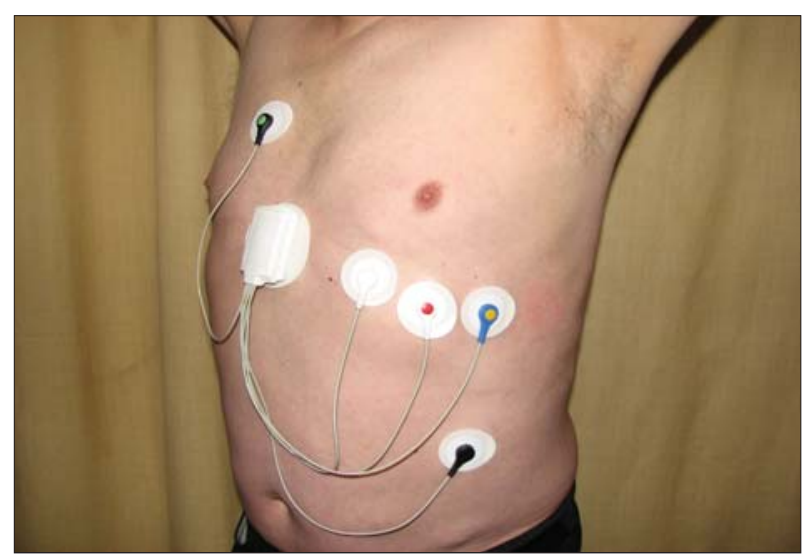

Figure 2. The developed system for registration the signals of 3 ECG leads and 3-axis accelerometer (inside of box) celerometer signals registration and transmission device (Fig. 2), computer and two packages of software. The first software package is intended for on-line analysis of vital signals and the second one - for comprehensive off-line analysis of stored data about athletes during monitoring.

A new ECG system consisting of five electrodes and three ECG leads has been proposed (Fig. 2): the first electrode is placed in the position of standard lead V1, the second one - V 4, the third one $-\mathrm{V} 5$, the fourth $-\mathrm{V} 6$, and the fifth electrode is placed bellow the chest.

Algorithm for evaluation of monitoring parameters. We described the data stream during monitoring using the convolution of Moore and Mealy automata (Berskiene et al., 2005). The data from ECG, respiration and motion parameters were obtained and evaluated by Mealy $\left(\mathrm{M}_{1}\right)$ automaton, later they were analyzed by Moore automata $\left(\mathrm{M}_{\mathrm{r}}\right)$.

Calculation of breathing frequency from the ECG data. It is important to have as much information from the processes which could be recorded in simple noninvasive way as possible. An ECG is such a process, and in spite of the fact that ECG seems much investigated, the investigators in many countries are looking for new information on ECG. One attempt was to find methods for the evaluation of the function of lungs according to ECG changes that were influenced by respiration. It is well known that during the deep breathing frequency of the heart rhythm increases in the inspiration phase and decreases in the expiration phase. It means that HR is influenced by the regulatory systems and directly-through the changing pressure in breast. It seems that evaluation of breathing according HR change is rather a simple task, but unfortunately, it is rarely used in clinical practice. The reason of such situation could be explained by the relation of heart rhythm variability on the frequency of the heart, i. e. the increasing frequency causes the decrease of dispersion.

Twenty eight female athletes $(22.6 \pm 0.43$ years old), involved in aerobics exercise program (2-3 times per week for 1.5 years) participated in the study. Personal monitor was fixed on each subject' $\mathrm{s}$ breast and all data were being recorded for 24 hours. The measures of the evaluation of all day activities were taken in the morning, an hour after they woke up, in the evening, at about $7-8$ p. m., and at night, about $2-3$ a. m. (Fig. 4 , upper curve). 


\section{RESULTS}

The developed on-line analysis software package performs the following functions:

- input and visualization of vital signals from registration device on the $\mathrm{PC}$ via Bluetooth interface (Fig. 3, bottom curves);

- storage of input data on the PC for later comprehensive off-line analysis;

- detection of QRS complex, calculation of HR, measurement of QRS duration and ST wave values in all three ECG leads, visualization of calculated parameters on the PC screen (Fig. 3, upper part);

- evaluation of athlete's activity and detection of "person markers" from the accelerometer data (Fig. 7);

- calculation of respiration frequency from the ECG data (Fig. 6);

- evaluation of athlete's functional state from calculated and measured parameters using Moore and Mealy automata algorithm (Berskiene et al., 2005) and formation of warning signals (green, yellow, red) (Fig. 3, upper part);

- writing the final report of athlete's monitoring (Fig. 8).

The criteria for the evaluation of ECG data are presented in Table 1 and the criteria for respiration frequency and motion activity evaluation are shown in Table 2.
Figure 3 presents the sample of screenshot: a table of calculated parameters (upper part) and input data (bottom part). Column HR (heart rate) includes data, estimated from current RR interval and in dHR - the difference of HR (dHR), estimated from current and previous RR interval, and column Cmp (comparison) contains the estimation of dHR ( $\mathrm{S}$ - the same, I - increased, D - decreased); the column DQrs the duration (in ms) of current QRS complex (DQrs), and in column dDQrs - the difference of duration between current and previous QRS complex (dDQrs), column Cmp - the estimation of dDQrs; column sST - the amplitude (in $\mu \mathrm{V}$ ) of deviation of current ST-segment from baseline, column dsST - the difference in amplitude between the current and the previous ST-segment (dsST), and column Cmp - the estimation of dsST. The following three columns (BR, dBR, $\mathrm{Cmp}$ ) present the results of estimation of breathing frequency (Bf), (times per minute), determined from ECG data. Then the next two columns (Acs, Cmp) indicate the patient's position ( $\mathrm{H}-$ horizontal, $\mathrm{V}$ - vertical), determined by 3 -axis accelerometer, as well as changes of this position ( $\mathrm{S}$ - the same, $\mathrm{A}$ - arise, L - lie down). The last columns (M, dM, Cmp) show the results of the estimation of movement (M) intensity, determined from $\mathrm{x}, \mathrm{y}, \mathrm{z}$ accelerometer signals. Finally, column Time indicates the time of recorded signals. The degree of parameter changes is

\begin{tabular}{|c|c|c|c|c|c|}
\hline \multicolumn{2}{|l|}{ Indices } & $\mathrm{I}=1$ & 2 & 3 & 4 \\
\hline For heart rate (HR) & $\begin{array}{c}\mathrm{b} / \min \\
\mathrm{HR}_{\mathrm{i}} \\
\Delta \mathrm{HR}\end{array}$ & $\begin{array}{c}0-40 \\
\text { the same } \\
\pm 25 \%\end{array}$ & $\begin{array}{c}40-100 \\
\text { higher } \\
>25 \%\end{array}$ & $\begin{array}{c}100-140 \\
\text { less } \\
<25 \%\end{array}$ & 140 and more \\
\hline $\begin{array}{c}\text { For QRS complex } \\
\text { duration (DQRS) }\end{array}$ & $\begin{array}{c}\mathrm{ms} \\
\mathrm{DQRS}_{\mathrm{i}} \\
\Delta \mathrm{DQRS}\end{array}$ & $\begin{array}{l}70-100 \\
\text { the same } \\
\pm 20 \%\end{array}$ & $\begin{array}{c}100-120 \\
\text { longer } \\
>20 \%\end{array}$ & $\begin{array}{c}120-140 \\
\text { shorter } \\
<20 \%\end{array}$ & \\
\hline $\begin{array}{c}\text { For ST-segment } \\
\text { amplitude in any ECG }\end{array}$ & $\begin{array}{c}\mathrm{ST}_{\mathrm{i}} \\
\Sigma / \mathrm{ST}_{\mathrm{i}} \\
\Delta \Sigma / \mathrm{ST}_{\mathrm{i}}\end{array}$ & $\begin{array}{c}0-0.1 \mathrm{mv} \\
\text { the same } \\
0-0.1 \mathrm{mV}\end{array}$ & $\begin{array}{c}>0.1 \mathrm{mV} \\
\text { bigger } \\
>0.1 \mathrm{mV}\end{array}$ & $\begin{array}{c}\text { less } \\
<0.1 \mathrm{mV}\end{array}$ & \\
\hline
\end{tabular}

Table 1. The criteria for the evaluation of ECG parameters

\begin{tabular}{|c|c|c|c|c|c|}
\hline \multicolumn{2}{|l|}{ Indices } & $\mathrm{I}=1$ & 2 & 3 & 4 \\
\hline $\begin{array}{c}\text { Evaluation of breathing } \\
\text { frequency } \\
(\mathrm{Bf})\end{array}$ & $\begin{array}{c}\mathrm{Bf} / \min \\
\mathrm{Bf}_{\mathrm{i}} \\
\Delta \mathrm{Bf}_{\mathrm{i}}\end{array}$ & $\begin{array}{c}0-6 \\
\text { the same } \\
\pm 25 \%\end{array}$ & $\begin{array}{l}6-10 \\
\text { higher } \\
>25 \%\end{array}$ & $\begin{array}{c}10-20 \\
\text { less } \\
<25 \%\end{array}$ & $>20$ \\
\hline Motion activity processes (Acs) & $\begin{array}{l}\text { Acs } \\
\text { Acs }_{i}\end{array}$ & $\begin{array}{c}\text { supine } \\
\text { the same }\end{array}$ & $\begin{array}{l}\text { upright } \\
\text { stands up }\end{array}$ & $\begin{array}{l}\text { urgent alarm } \\
\text { lie-down }\end{array}$ & \\
\hline Evaluation of movement (M) & $\begin{array}{l}\mathrm{M} \\
\mathrm{M}_{\mathrm{i}}\end{array}$ & $\begin{array}{c}\text { stationary } \\
\text { the same }\end{array}$ & $\begin{array}{c}\text { small } \\
\text { higher }\end{array}$ & $\begin{array}{c}\text { high } \\
\text { less }\end{array}$ & \\
\hline
\end{tabular}

Table 2. The criteria for the evaluation of respiration frequency and motion activity data 
Figure 3. The sample of screenshot: table of calculated parameters (upper part) and input data (bottom part), 3 ECG leads (upper curves) and 3 channel motion signals (bottom curves)
Figure 4. Dynamics of $\mathbf{H R}$ and $\mathbf{R}$ wave amplitude variability during 24 hours
Figure 5. Dynamics of $H R$ and $R$ wave amplitude variability during aerobic exercises
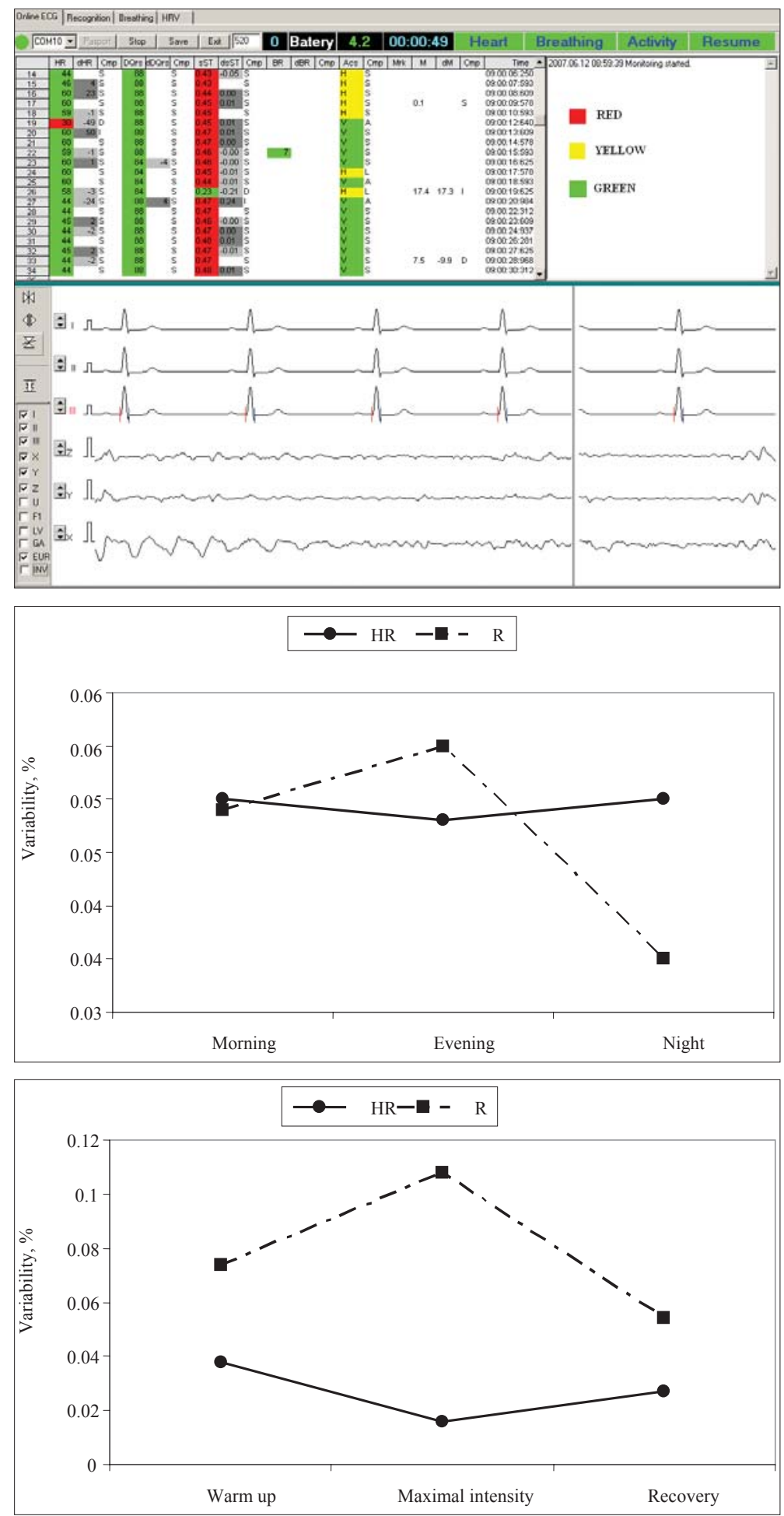

indicated by different colors: green - normal, without any changes, yellow - limitary changes, red - great abnormal changes in parameters or functional state.

Input data (Figure 3, bottom) consist of three ECG leads D1, D2, D3 (fD1 $=\Phi 1-\Phi 2$, $\mathrm{D} 2=\Phi 1-\Phi 3, \mathrm{D} 3=\Phi 1-\Phi 4$, where $\Phi 1, \Phi 2, \Phi 3$, $\Phi 4$ are potentials, recorded in 1, 2, 3 and 4 points) and 3 motion signals (the last three curves in the underside of Figure 3 represent the intensity of body movement in horizontal (x), vertical (y) or transversal (z) directions).

The real time software for personal monitor is created by using plain $\mathrm{C}^{++}$and it can run on different PC platforms.

In the training session three points during the warm up, the maximal activity, and the recovery have also been taken (Fig. 4, bottom curve). It is easy to see that in the day time, when HR changes are not so meaningful, the changes of HR variabi- 

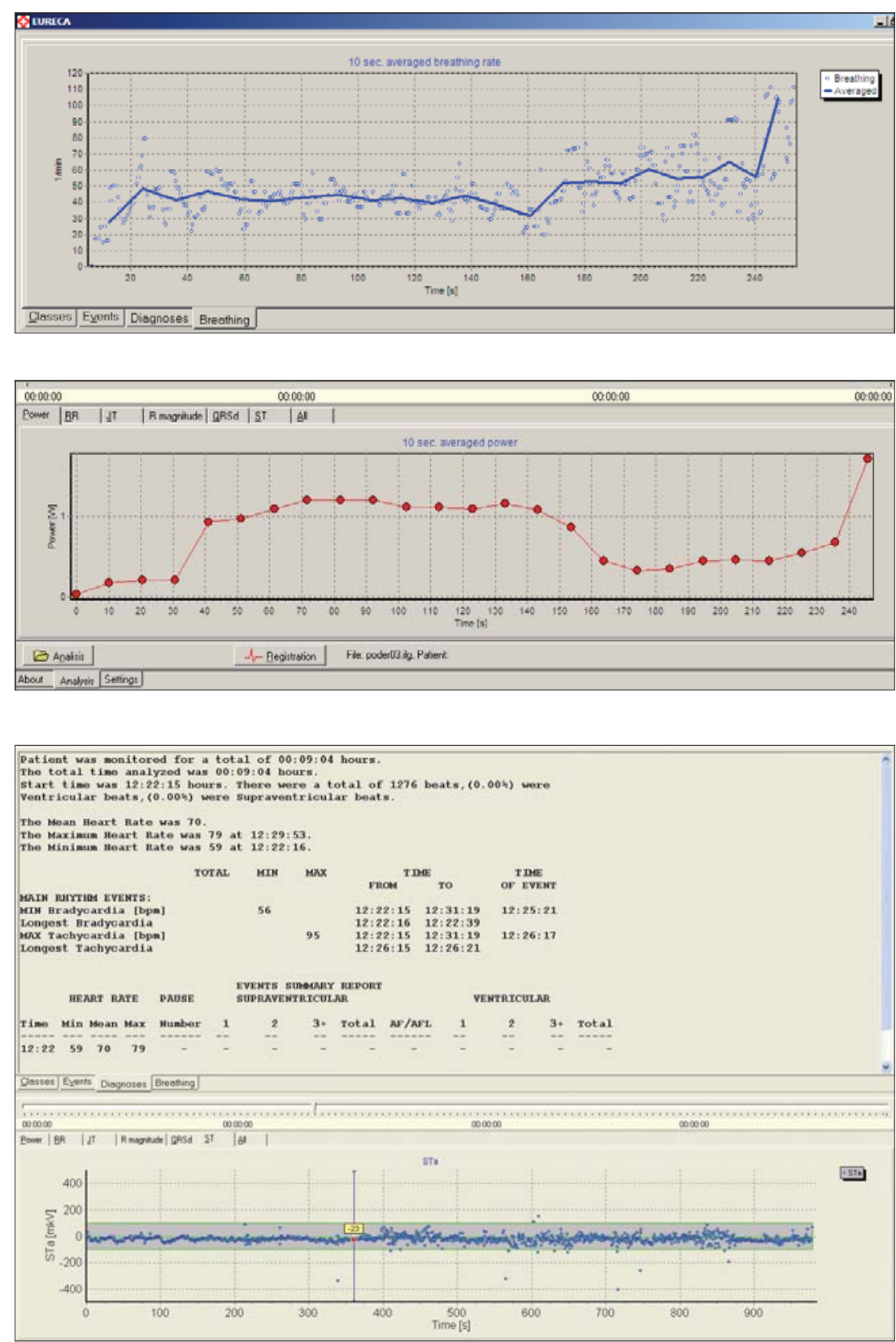

Figure 6. Results of evaluation of respiration frequency from RR amplitudes
Figure7. Results of evaluation of athlete's activity, developing power $(\mathrm{W})$

Figure 8. Final report of athlete's monitoring lity $(\mathrm{Va}=\mathrm{SD} /$ mean $)$ are marginal also, but during aerobic fitness training the variability drops down significantly, and in this case the evaluation of breathing becomes problematic. Another problem is the disturbances of the heart rhythm, when the sequence of heart beats dramatically changes.

Seeking to increase the accuracy of the evaluation of the breathing frequency we have to find other means on ECG which could reflect the breathing process. A stroke volume is about $100 \mathrm{ml}$ of blood during every beat. When a greater amount of blood flows to the lungs, the resistance of the breast decreases. ECG shows it as a change of R wave amplitude. An augmentation of load causes the increase of stroke volume, and the changes of $\mathrm{R}$ wave increase too. For the same students the changes of $\mathrm{R}$ amplitude in the same situations during the day (Fig. 5, bottom curve) and during aerobic exercise (upper curve) were evaluated. As it was expected, during load the variability of $\mathrm{R}$ wave increased, which means that this parameter could improve the accuracy of the estimation of breathing.

According to the information obtained from individual detailed investigation of $\mathrm{R}$ wave amplitude changes, algorithm for calculations of breathing frequency was developed. The first step was to choose an interval in which the frequency would be calculated, for example, from $10 \mathrm{~s}$ to $30 \mathrm{~s}$, the longer interval could lead to overlooking some sudden breathing problems. In the chosen interval the QRS complexes were detected and R 
wave amplitude, together with RR intervals (interval between two adjacent QRS complexes) were measured (Fig. 6 a). The mean value of R amplitude and RR interval were calculated. The ratio of individual parameter to the mean for every beat was calculated, too. With accuracy $\varepsilon$ in the chosen interval the maximal and minimal values of $\mathrm{R}$ wave amplitude and RR intervals were detected. The intervals between the detected maximal and minimal values were calculated and the means of both were obtained. These mean values represent the frequency of breathing.

Off-line analysis of stored monitoring data. The on-line monitoring program always records ECG and motion activity data to PC hard disk. These data are intended for the analysis using mathematical and expert methods, and results are assigned for medical or coaching staff. For this purpose the off-line software for comprehensive analysis of stored person monitoring data was developed. The off-line software performs the following functions:

- recognition and measurement of ST-segment changes, JT interval duration, RR interval duration and visual representation in a time domain;

- using R wave's magnitudes and RR time interval sets, calculation of respiration frequency and presentation it in visual time domain format (Fig. 6);

- QRS complex detection and classification to determined classes;

- representation of monitoring data and events in time domain, selection of the event environment, measurement of magnitude and duration;

- calculation of set disperson of values of $\mathrm{R}$ an $\mathrm{S}$ wave's magnitude, relation of JT and RR time intervals and presentation of visual results in Poincare diagram and time domain format;

- determination of the patient's position (horizontal or vertical), evaluation of the patient's activity (Fig.7), and detection of "patient markers" from the accelerometer data;

- writing the final report of the patient's monitoring results (Fig. 8).

After the recognition of QRS complex its marks of onset and offset were defined, the measurement of QRS duration and determination shape was performed, and the classification of QRS to five classes was accomplished: normal beats $(\mathrm{N})$, supraventricular beats $(\mathrm{S})$, ventricular beats (V), fussion beats (F), pacemaker beats $(\mathrm{Q})$, and unclassified complexes (U) formed the last group.

Figure 6 presents means of breathing frequency, detected from oscillations of $\mathrm{R}$ wave during inspiration and expiration. After $200 \mathrm{~s}$ from the beginning of the investigation the athletes were asked to breath frequently; the developed algorithm gave the correct result, and actual results matched the results obtained in the program.

The sample of results of the evaluation of the athlete's activity could be observed in Figure 7: till the fiftieth second of the investigation the athletes were resting, and after load was increased up to $450 \mathrm{~W}$ till the end of the investigation (400 s).

The beginning of the final repeat (Figure 8) gives the statistics of detected rhythmic disorders: the total monitoring time, the starting time of the investigation, the total number of recorded heart beats, and among them - the number of abnormal ventricular and supraventricular heart beats with ratio (in percent) to all beats. Then the maximal and minimal HR values are presented, and the results of detailed analysis of detected arrhythmic events are supplied. In the bottom part of Figure 8 , the trend of ST-segment displacement (in $\mu \mathrm{V}$ ) STa from baseline during the whole period of investigation can be observed.

The off-line software package is created using plain $\mathrm{C}++$ and it works in the WINDOWS environment with the PC PENTIUM-IV $3 \mathrm{GHz}$ processor about $5 \mathrm{sec}$ for data record 1 hour duration and 6 channels by $500 \mathrm{~Hz}$ sampling rate. In the nearest future the developed personal monitor with patient functional state evaluation software will be tested according IEC 60601-2-47:2001 using standard data bases.

The investigations of respiration frequency (28 female students during their every day life for $24 \mathrm{~h}$ and during their aerobic fitness training) from ECG parameters during physical load showed the adequacy with real situation.

\section{DISCUSSION}

Many methods for the assessment of energy expenditure under daily living conditions, such as monitoring HR, or physical activity level measured by doubly labeled water and accelerometry, accelerometry combined with HR telemetry, por- 
table global positioning units in complement with accelerometry were proposed (Hoos et al., 2003; Kumahara et al., 2004; Rodriguez et al., 2005). It was shown that a combination of HR and accelerometry as well as accelerometry alone could serve as a method for the assessment of energy expenditure during daily living activities (Kumahara et al., 2004; Karantonis et al., 2006). In the developed ECG and motion activity monitoring system, the proposed decision algorithm based on the convolution of Moore and Mealy automata and two packages of software on-line and off-line data analysis were implemented. The software for the evaluation of the patient's activity was tested on 11 healthy students with a mean age of 20.6 (S.D. 3.3) years by using the mobile device during the performance of activities of various intensities. The integration period was set at $10 \mathrm{~s}$, and the final output was expressed as integrated physical activity level. The increase in physical activity level during the brisk walk was $1.40 \pm 0.12$ times higher as compared to the one during the slow walk (it corresponds to motion level 2 presented in Table 2), and during the jogging session it was $1.89 \pm 0.14$ times higher than during the slow walk (it corresponds to motion level 3 presented in Table 2).
Literature analysis shows an increasing interest in the application of information technologies in sports training (Vainoras, 2002; Kellerman, 2006; Poderys, 2006). The aim of the EUREKA project "Mobile Personal ECG Monitor, HEART GUARD" was to develop a new device for monitoring cardiovascular functioning under daily life conditions and to develop and implement the monitoring of physical activity into the system using accelerometers and wireless technologies of data transmission.

\section{CONCLUSION}

The results obtained during the investigations show that the developed ECG and motion activity monitoring system with two packages of software allows to measure cardio respiratory changes and changes in the intensities of physical activity during the training session and under daily living conditions.

Acknowledgements. This work was supported by Grant from the Agency for International Science and Technology Development Programs in Lithuania within the EUREKA Project E!3489 "Heart Guard. Mobile Personal ECG Monitor".

\section{REFERENCIES}

Berskiene, K., Aseriskyte, D., Navickas, Z., Vainoras, A. (2005). Development of information system for E - health using Mealy and Moore automata. Mathematics and Mathematical Modelling, 1, 48-54.

Cross, N. (1999). Individualization of training programmes. In N. Cross and J. Lyle (Eds.), The Coaching Process: Principles and Practice for Sport. Oxford: Butterworth Heinemann. P. 174-191.

Glaros, C., Fotiadis, D. I., Likas, A., Stafylopatis, A. (2002). A wearable platform for the monitoring of the athlete's health condition and performance. In Proc of the International Federation for Medical and Biological Engineering, EMBEC'02, Vienna, Austria. Dec 4-8, 3 (1), 348-349.

Hoos, M. B., Plasqui, G., Gerver, W. J., Westerterp, K. R. (2003). Physical activity level measured by doubly labeled water and accelerometry in children. European Journal of Applied Physiology, 89 (6), 624-626.

Karantonis, D. M., Narayanan, M. R., Mathie, M., Lovell, N. H., Celler, B. G. (2006). Implementation of a real-time human movement classifier using a triaxial accelerometer for ambulatory monitoring. IEEE Transactions of Information Technology in Biomedicine, 10 (1), 156-167.
Kellerman, N. (2006). Rowing and Sports Performance Monitoring. Internet site address: http://www.nkhome. com

Korsakas, S., Lauznis, J., Vainoras, A. et al. (2006). The Mobile ECG and Motion Activity Monitoring System for home care patients. Computers in Cardiology, Vol .33, $833-837$.

Kumahara, H., Schutz, Y., Ayabe, M. et al. (2004). The use of uniaxial accelerometry for the assessment of physicalactivity-related energy expenditure: A validation study against whole-body indirect calorimetry. British Journal of Nutrition, 91 (2), 235-243.

Poderys, J. (2006). Validity of uni-axial and tri-axial accelerometry for monitoring of physical activity at stadium and free living conditions. Sports Science, 3, 32-34.

Rodriguez, D. A., Brown, A. L., Troped, P. J. (2005). Portable global positioning units to complement accelerometry-based physical activity monitors. Medicine and Science in Sports and Exercise, 37 (Suppl. 11), 572-581.

Vainoras, A. (2002). Functional model of human organism reaction to load - evaluation of sportsman training effect. Ugdymas. Küno kultūra. Sportas, 3, 88-93. 


\title{
TIESIOGINĖS IR NETIESIOGINĖS SPORTININKUৃ ELEKTROKARDIOGRAMOS IR JUDE்JIMO AKTYVUMO STEBĖSENOS SISTEMA
}

\author{
Stasys Korsakas ${ }^{1}$, Alfonsas Vainoras ${ }^{1}$, Liudas Gargasas ${ }^{1}$, Vytenis Miškinis ${ }^{1}$, Rimtautas Ruseckas ${ }^{1}$, \\ Vidmantas Jurkonis ${ }^{1}$, Algè Vitartaité ${ }^{1}$, Jonas Poderys ${ }^{1,2}$ \\ Kauno medicinos universitetas ${ }^{1}$, Lietuvos kūno kultūros akademija ${ }^{2}$, Kaunas, Lietuva
}

\begin{abstract}
SANTRAUKA
Tikslas — pristatyti naują tiesioginio ir netiesioginio sportininkų EKG ir judèjimo aktyvumo stebėsenos sistemą. Sukurtoji sistema yra skirta treneriams - elito sportininkų treniruotės vyksmui individualizuoti ir optimizuoti.

Sistemą sudaro techninè ir programinè ịranga: techninę - EKG ir akcelerometrinių signalų registravimo ir bevielio perdavimo į kompiuterị irenginys; programinę — du programų paketai: tiesioginès stebėsenos duomenų analizès treniruotès metu ir netiesioginès stebėsenos duomenų, sukauptų kompiuterio atmintyje, išsamios analizès po treniruotès.

Norint tiesioginès stebėsenos metu įvertinti sportininku funkcinę būseną iš EKG parametrų, kvèpavimo dažnio ir judejjimo aktyvumo, buvo panaudotas Moore ir Mealy automatų algoritmas. Programą sudaro trijų tipų signalai, informuojantys apie sportininko būseną: žalia spalva - normali, geltona — ribinè, raudona - grèsminga. Sukurtas naujas kvėpavimo dažnio įvertinimo metodas ir patikrintas testuojant 28 sportininkus aerobikos pratybų metu. Daugeliu atvejų sukurtoji programa sportininkų kvèpavimo dažni ¿̇vertino tiksliai. Sportininkų judejjimo aktyvumo vertinimo programa patikrinta vienuolikai studentų einant, bėgant ir atliekant šuolius.

Gauti rezultatai atskleidè, kad fizinio aktyvumo lygis bėgimo metu buvo aukštesnis 1,4 karto ir 1,89 karto - atliekant šuolius, palyginti su lètu ejjimu. Sukurtosios sistemos ir kvėpavimo dažnio įvertinimo preliminarūs testavimo rezultatai parodè, kad tiesioginio EKG ir judejjimo aktyvumo stebèsenos sistema gali būti panaudota sportininkų būsenai stebèti treniruočių metu, o išsami stebèsenos duomenų analizè po treniruotės leis treneriui tiksliau ịvertinti judejjimo užduočių atlikimo kokybę taip pat širdies ir kraujagyslių, kvẻpavimo sistemų funkcijos kitimą per pratybas.
\end{abstract}

Raktažodžiai: sportininkų stebėsenos sistema, elektrokardiograma, akcelerometrija, kvèpavimo dažnis.

Gauta 2007 m. birželio 13 d.

Received on June 13, 2007

Priimta 2007 m. rugsèjo 19 d.

Accepted on September 19, 2007
Stasys Korsakas

Kaunas University of Medicine

(Kauno medicinos universitetas)

Sukilèliu str. 17-107, LT-50009 Kaunas

Lithuania (Lietuva)

Tel +370 37792515

E-mail stakor@medi.lt 